KS. MAREK ŁANGOWSKI

Wyższe Seminarium Duchowne w Pelplinie

\title{
ALEXIS CARREL I AKTION T4, CZYLI EUGENIZM W WALCE PRZECIWKO MISTERIUM OSOBY LUDZKIEJ
}

Alexis Carrel z nazistowską Aktion T4 nie ma związku bezpośredniego. Jednak jego teorie eugeniczne wydają się być łudząco podobne do elementarnych hitlerowskich założeń doskonalenia jednostki i narodu. Moment dziejowy, który połączył eugeniczne aspiracje uczonych i polityków miał swoje zakorzenienie w głębokim kryzysie ówczesnego świata. Alexis Carrel i Adolf Hitler prawdopodobnie nigdy się nie spotkali. Jednak wydaje się, że ten ostatni znał teorie eugenizmu swojej epoki, a uznając się za luminarza w dziedzinie doskonalenia człowieka, dokonał zbrodni, która do dziś pozostaje jedną z najbardziej tajemniczych i nieopisanych wydarzeń minionego wieku. Jest ona szczególnie bestialska, gdyż dotknęła ludzi najsłabszych, chorych i niepełnosprawnych psychicznie. W nazistowskich Niemczech zamordowano blisko 300000 osób chorych i niepełnosprawnych. Ta liczba z pewnością jest niepełna, nie obejmuje ofiar aborcji, eksperymentów medycznych i przymusowej sterylizacji podejmowanej ze względu na podejrzenie obciążeń genetycznych. Nie obejmuje ona również zbiorowych mordów popełnionych na osobach chorych i niepełnosprawnych, dokonanych w krajach wcielonych do III Rzeszy, ponieważ tych nie rejestrowano. Po 1 września 1939 roku Niemcy nazistowskie rozpoczęły szeroki program likwidacji chorych i niepełnosprawnych w Polsce. Polskie ofiary na północnych i zachodnich terenach kraju nigdy nie były ujęte w niemieckich statystykach. Zazwyczaj mordowane były strzałem w potylicę, jak np. ponad 2000 osób w piaśnickim lesie (Piasnitz) ${ }^{1}$. Między innymi na Pomorzu, w samym tylko Szpitalu w Kocborowie (Konradstein), dzielnicy Starogardu Gdańskiego, do końca 1939 roku zamordowano około 2000 pacjentów ${ }^{2}$, w tym 500 dzieci. Użyto do tego zabójczych dawek

M. Tregenza, Aktion T4. Le secret d'Etat des nazis: l'extermination des handicapés physiques et mentaux, Calmann-Lévy, Paryż 2011, s. 111.

2 W. Kulesza, „Euthanasie - Morde an Polnischen Psychiatriepatient/innen während des Zweiten Weltkriegs”, w: M. Rotzoll, G. Hohendorf, P. Fuchs i in., Die nationalsozialistische „Euthanasie“ 
fenobarbitalu, znanego pod nazwą „Luminal” leku o działaniu nasennym i uspokajającym. Truciznę tę wykorzystano dla zaoszczędzenia amunicji. Zbrodni dokonywano na wyraźny rozkaz kanclerza Niemiec. Adolf Hitler już przed wojną, pisząc „Mein Kampf” deklarował, iż pomnożenie siły etnicznej narodu niemieckiego będzie możliwe tylko wtedy, gdy usunie się ze społeczeństwa jednostki najsłabsze, ponieważ powodują one obciążenie finansowe dla państwa i zagrażają jego produktywności. Dla Hitlera i piewców nazizmu ideologia eugenizmu z pewnością nie była czymś nowym. Wśród prekursorów niemieckiej eugeniki jest wiele nazwisk: Ernst Haeckel, Wilhelm Schallmayer, Ludwig Woltmann, Alfred Ploetz, Alfred Grotjahn. Teoria eugenizmu Alexisa Carrela jest w tej perspektywie dla nazistów głosem ważnym, mimo że on sam nie był Niemcem. Carrel był przede wszystkim lekarzem, chirurgiem i laureatem Nagrody Nobla. Głośna była jego rzekoma fascynacja historią pewnego uzdrowienia w Lourdes. Nie bez znaczenia było również to, że został przyjęty w poczet naukowców Papieskiej Akademii Nauk.

\section{ALEXIS CARREL I JEGO TEORIA EUGENIZMU}

W 1935 roku Alexis Carrel, francuski biolog i chirurg, na prośbę swoich amerykańskich przyjaciół publikuje w języku angielskim książkę „Man, The Unknown"3, w której daje jasny wyraz przyjęcia postawy faworyzującej eugenizm i eutanazję, w szczególności dla ciężkich przestępców, nierokujących na resocjalizację. W epoce darwinizmu przyjmowano, że przestępczość zapisana jest w genach ${ }^{4}$. Eugenizm Carrela karmił się teoriami będącymi w modzie w Stanach Zjednoczonych, które coraz bardziej zyskiwały tam na popularności w społeczeństwie dotkniętym kryzysem gospodarczym, zapoczątkowanym przez krach finansowy na Wall Street w 1929 roku. Alexis Carrel w 1906 roku podjął pracę w Instytucie Badań Medycznych Rockeffelera w Nowym Jorku, gdzie pracował nad transplantologią organów. Skupił się szczególnie na chirurgii sercowo-naczyniowej i w 1910 roku wykonał pierwszy eksperymentalny zabieg pomostowania aortalno-wieńcowego (bypass). W 1912 roku otrzymał Nagrodę Nobla w dziedzinie fizjologii i medycyny. W Polsce znany jest szczególnie z powodu swoich zainteresowań uzdrowieniami dokonującymi się w Lourdes. Zafascynowany cudem uzdrowienia młodej kobiety umierającej na gruźlicę otrzewnej w maju 1903 roku, podjął szereg badań, które w końcu przekonały go o cudownym charakterze tych

- Aktion , T4“ "und ihre Opfer. Geschichte und ethische Konsequenzen für die Gegenwart, F. Schöningh, Paderborn/München 2010, s. 175.

3 Książka opublikowana w Polsce w 1938 r. pt. „Człowiek, istota nieznana” nakładem wydawnictwa Trzaska, Evert i Michalski S.A.

4 Zob. Cesare Lombroso. 
wydarzeń. W 1936 roku Alexis Carrel został przyjęty w poczet naukowców Papieskiej Akademii Nauk. Na stronie internetowej tej instytucji można jeszcze dziś przeczytać w biogramie opracowanym przez o. Agostino Gemelli, iż książka „Człowiek, istota nieznana” zawiera w swoim programie „,demonstrację harmonii nauki i wiary w przekonaniu, iż nauki biologiczne posiadają ograniczenia, dzięki którym nie można powiedzieć wszystkiego o tym, kim jest człowiek"s. Prawdą jest, iż książka Carrela w ciągu kilku lat spotkała się z ogromnym zainteresowaniem i została przetłumaczona na kilka języków. We Francji, jako „L’homme, cet inconnu" ukazała się w tym samym roku, co wydanie amerykańskie. W Niemczech natomiast, po raz pierwszy, jako „Der Mensch, Das unbekannte Wesen”, książkę wydało Deutsche Verlags-Anstalt w Stuttgarcie w 1936 roku. Do tego wydania Alexis Carrel napisał wstęp, w którym chwali środki przedsięwzięte przez rząd niemiecki dla ograniczenia liczebnego wzrostu mniejszości, obłąkanych i kryminalistów. Kolejne publikacje miały miejsce w 1940, 1950, 1955 i 1957 roku.

Nie brakuje tych, którzy bronią Alexisa Carrela, twierdząc, iż ponad wszystko jest on pionierem transplantologii i noblistą, oraz że jego propozycje dotyczące eugenizmu wpisywały się $\mathrm{w}$ epokę darwinizmu łączonego z systematyką organizmów. Nie zmienia to jednak faktu, że jego tezy eugenistyczne pozostają w bardzo poważnej sprzeczności z etyką chrześcijańską i nauką społeczną Kościoła. Stał się on gorliwym piewcą eugenizmu w swojej potrójnej teorii organicznego przetrwania, genetycznej reprodukcji i postępu psychizmu przez ewolucję, a słowa z jego książki nie pozostawiają złudzeń: „Aby elita mogła trwać, eugenizm jest niezastąpiony. Jest oczywistym, że rasa musi rozmnażać swoje najlepsze elementy. Tymczasem, w narodach cywilizowanych, reprodukcja spada i daje jednostki niższego rzędu"6. Segregacja według Carrela musi dokonywać się już na etapie przed zapłodnieniem: „Eugenizm dobrowolny jest nie do zrealizowania. Bez wątpienia, miłość tchnie tak samo mimowolnie jak wiatr. Jednak wiara w tę cechę miłości jest wstrząśnięta przez fakt, że pewni młodzi mężczyźni zakochują się jedynie w bogatych dziewczętach, i vice versa. Jeśli miłość jest zdolna do dawania posłuchu sile mamony, to być może usłucha również tak praktycznych wskazówek, jak właśnie te, które dotyczą zdrowia. Nikt nie powienien poślubiać jednostki, która jest nosicielką wad wrodzonych"ᄁ . W tych warunkach stawianych ludzkości,

5 Tłumaczenie autora z języka włoskiego: "Di lui anche il grande pubblico ricorda il volume L'homme cet inconnu che nel programma dell'autore volle essere la dimostrazione dell'armonia di scienza e fede nel riconoscimento che le scienze biologiche hanno limiti per i quali non ci possono dire tutto ciò che è l'uomo".

Zob. http: //www.casinapioiv.va/content/accademia/it/academicians/deceased/carrel.html (30.6.2018).

6 A. Carrel, L’homme, cet inconnu, Plon, Paryż 1935, s. 287. Wszystkie tłumaczenia tekstów obcojęzycznych pochodzą od autora artykułu.

7 Tamże, s. 288. 
Carrel nie zawahał się pójść aż do próby stworzenia fałszywej mistyki wyrzeczenia i ofiary, mającej na celu ochronę najwyższego dobra cywilizacji, którym miał być według niego rozwój osobowości ludzkiej. Etyka i współczucie powinny uznać wyższość owego zadania: „Systemy filozoficzne i sentymentalne przesądy powinny zniknąć wobec tej konieczności"». Carrel uważał, że zna prawdę o przeznaczeniu człowieka i posiada wiedzę o tym, w jaki sposób uczynić ludzkość szczęśliwą. Jego sposób procedowania nie jest daleki od logiki ideologii totalitarnej rozwijającej się w tym samym czasie. Głosi on, iż ludzkość ma być wyzwolona z ciężaru chorób i kalectwa przez ślepe posłuszeństwo względem eksperta, względem umysłu najbardziej światłego, który przez swe zdolności analityczne stanie się uzdrowicielem całej cywilizacji.

\section{AKTION T4 I EUGENIZM STOSOWANY W NAZISTOWSKICH NIEMCZECH}

Idee eugeniczne z łatwością znajdowały zwolenników w przedwojennych Niemczech jeszcze przed publikacją Carrela. Jego książka była jednak czytana w tym kraju z fascynacją przed i, co ciekawe, również po wojnie. Ludzkość nie musiała czekać długo, aby ujrzeć szaleńca, który uwierzył w swoją misję odnowienia człowieka i uczynienia go zdrowym, silnym i doskonałym. Był nim Adolf Hitler, który po swoim dojściu do władzy wcielał w życie kraju politykę eugeniczną mającą na celu ochronę rasy aryjskiej przed wszystkim, co mogło ją rzekomo osłabić i zdegenerować. W 1933 roku w Niemczech zostało ogłoszone prawo dotyczące sterylizacji osób posiadających wady, które mogły być uważane za dziedziczone. Przepisy te weszły w życie 1 stycznia 1934 roku. W roku następnym, 8 października, ustanowiono prawo, które zezwalało rodzicom na aborcję płodu niepełnosprawnego lub chorego. Wkrótce kierownictwo sanitarne III Rzeszy erygowało 500 ośrodków segregacji, w których zbierane były informacje dotyczące osób przeznaczonych do sterylizacji oraz dzieci cierpiących na niepełnosprawność. Służby sanitarne kraju rozpoczęły eliminację dzieci niepełnosprawnych w wieku poniżej trzech lat. Poufna nota rządowa z 18 sierpnia 1939 roku już obligowała oddziały porodowe do deklaracji wszystkich niepełnosprawnych noworodków. Rodzice tych dzieci byli proszeni o oddanie ich do wyspecjalizowanych lecznic, w których dokonywano tajnych eutanazji. Na terenach Austrii i Niemiec istniało sześć miejsc, w których uśmiercano chorych i niepełnosprawnych tlenkiem węgla w pomieszczeniach murowanych lub spalinami w samochodowych komorach gazowych. Były to miejscowości: Grafeneck, Brandenburg, Hartheim, Sonnenstein, Bernbourg, Hadamar w Hesji. Każde z tych miejsc było wyposażone w niby łaź-

Tamże, s. 306. 
nie, które w rzeczywistości były komorami gazowymi. Osoby, które były do nich transportowane, niejednokrotnie zabijane były już w samochodach, przy użyciu spalin. Wszystkie ciała ofiar były spalane w krematoriach, które istniały tuż obok. Rodziny zabitych otrzymywały oficjalny list z informacją, iż osoba chora lub niepełnosprawna zmarła z powodu choroby zakaźnej, a jej ciało skremowano z przyczyn sanitarnych. Te masowe mordy, nazywane eutanazją, były częścią polityki eugenicznej.

Wiadomym jest, iż mimo podjęcia eugenicznych działań represyjnych kilka lat wcześniej, zarządzenie eutanazji datowane było przez Hitlera na 1 września 1939 roku, czyli na dzień rozpoczęcia wojny „zewnętrznej” z Polską przeciwko narodowi, który dyktator poprzysiągł zniszczyć. Nie jest to bez znaczenia, gdyż systemowa eutanazja określana eufemizmem Gnadentod, czyli „łaskawej śmierci”, posiadała też miano wojny „,wewnętrznej”. . Obie wojny, według Hitlera, posiadały tę samą wagę dla narodu niemieckiego. Program nazwany Aktion T4 rozpoczyna swoją działalność w tajemnicy przed społeczeństwem, kierowany przez Reichsleitera Philippa Bouhlera i doktora medycyny Karla Brandta, w siedzibie przy ul. Ogrodu Zoologicznego 4 (Tiergartenstrasse 4) w Berlinie. Dla tej nowo powołanej instytucji osoby niepełnosprawne fizycznie i umysłowo są wcieleniem wewnętrznego wroga Rzeszy. W ten sposób, w samym tylko 1940 roku 35224 osoby były pozbawione życia, według raportu zredagowanego przez Eduarda Brandta, nazistowskiego statystyka. Stwierdził on, iż „wychodząc z hipotezy, że utrzymanie jednego pacjenta w azylu kosztuje 3,50 RM dziennie, codzienne oszczędności oscylowały wokół 245 955,50 RM, a oszczędności roczne wokół 88543980 RM" Dokument Brandta potwierdza charakter utylitarny programu, gdyż jego statystyki szczegółowo wyliczają oczekiwane oszczędności aż do roku 1951, określając je na poziomie $885439800 \mathrm{RM}$.

W „Tysiącletniej Rzeszy” celem było zwalczenie wszystkiego, co mogło szkodzić wyjątkowości i wyższości wielkiego narodu niemieckiego, które były traktowane jako jego zdrowie. Nazizm był postrzegany jako ,zaaplikowana biologia”. Adolf Hitler stał się w tej ideologii „wielkim lekarzem narodu”, a eutanazja „terapią" związaną z „higieną rasową" "11, nazywaną również w sposób eufemistyczny „wyzwoleniem”, ,przerwaniem życia”, „śmiercią miłosierną”, ,pomocą w odejściu" ${ }^{2}$. Propaganda była tak bardzo ekspansywna i skuteczna, że społeczeństwo niemieckie było przerażone możliwością istnienia ciężkich chorób i kalectw. Począwszy od 1938 roku to opinia publiczna kierowała do Hitlera żądania, by remedium „śmierci miłosiernej” mogło być stosowane w pewnych

M. Tregenza, dz. cyt., s. 125.

10 Tamże, s. 387.

11 Tamże, s. 49.

12 G. Aly, Les Anormaux. Les meurtres par euthanasie en Allemagne (1939-1945), Flammarion, Paryż 2013, s. 9. 
przypadkach ${ }^{13}$. Podawane były liczne pseudonaukowe argumenty ideologiczne. Sam Hitler uważał, że eutanazja praktykowana w Sparcie była działaniem „tysiąc razy bardziej ludzkim, niż przeklęte współczesne otępienie, które podtrzymuje przy życiu przypadki najbardziej patologiczne"14. Darwinizm społeczny, który legitymizował przekonanie, że postęp ludzkości zależy wyłącznie od najbardziej uzdolnionych, a najbardziej słabi są do wyeliminowania, powodował prawdziwe „pranie mózgów” w społeczeństwie niemieckim. Masowe przekonanie, że „martwy balast” $i$,ppasożyty społeczne” powinny zostać usunięte z narodu niemieckiego, $\mathrm{z}$ biegiem lat przybierało na sile. Propaganda przedstawiała Hitlera jako objawiciela nowego sensu życia ${ }^{15}$.

\section{TYRANIA TEORETYCZNEJ DOSKONAŁOŚCI CZŁOWIEKA WBREW MISTERIUM OSOBY LUDZKIEJ}

Teoretyczny eugenizm Alexisa Carrela, będący częścią jego utopii, obierał sobie za cel rozwój cywilizacji zdrowej i wolnej od mentalnej degeneracji. Praktyczny eugenizm Hitlera był z kolei postrzegany jako narzędzie dla rozwoju gospodarki Rzeszy. Obydwa czyniły z bezbronnej osoby ludzkiej głównego wroga społeczeństwa, próbując odebrać jej godność i dehumanizując. Człowiek chory lub niepełnosprawny był przez te ideologie obdarty ze swojej celowości i odrzucony jako odpad i przeszkoda, zarazem w rozwoju cywilizacji, jak i w drodze do postępu. Wyeliminowanie osoby wulnerabilnej ${ }^{16}$, wymagającej pomocy i zależnej od innych, staje się wymogiem owego postępu zakładanego przez ideologię totalitaryzmu. Taka teoria wprowadza z góry fałszywe założenia, że osoba wulnerabilna jest błędem, którego należy unikać oraz że nie powinna ona być częścią rzeczywistości. Postęp ludzkości w kierunku ideału „naprawdę wspaniałych okazów bytów ludzkich" ${ }^{17}$ nie pozostawia miejsca dla misterium osoby. Tyrania jedynej poprawnej wizji doskonałości ludzkiej, ściśle związanej ze zdrowiem psychicznym, siłą fizyczną i narzuconym kanonem harmonii i piękna ciała, stała się w nazistowskich Niemczech i krajach okupowanych przyczyną nieszczęścia setek tysięcy istnień.

13 M. Tregenza, dz. cyt., s. 49.

14 Tamże, s. 76.

15 K.D. Bracher, Hitler et la dictature allemande. Naissance, structure et conséquence du NationalSocialisme, Éd. Complexe, Paryż 1995, s. 207.

16 Neologizm „wulnerabilność” oznacza podatność na zranienie, zniszczenie, wyeliminowanie. Zob. M. Łangowski, Wulnerabilność w życiu i filozofii Emmanuela Mouniera, „Studia Pelplińskie” 2016, t. XLIX, s. 215-228.

17 A. Carrel, dz. cyt., s. 16. 
To dzięki posłuszeństwu niemieckich obywateli naziści byli w stanie osiągnąć swój cel. Społeczeństwo niemieckie w znacznej mierze przyzwoliło na legislację zbrodniczego prawa eugenicznego i eutanazyjnego. Stąd była już prosta droga do największych zbrodni przeciwko ludzkości. Götz Aly, współczesny historyk, dziennikarz i pisarz niemiecki, określa wprost Aktion T4 jako wstęp do masowych mordów ludności Europy w obozach koncentracyjnych. Jeśli zbrodnia o tak wielkim zasięgu jak Aktion T4 mogła być przeprowadzona w całych Niemczech, to również dlatego, że było na to przyzwolenie społeczeństwa: „Ponieważ Niemcy przyzwolili na mord pasożytów społecznych, przywódcy polityczni mieli pewność, że mogą popełnić zbrodnie jeszcze większe, bez jakiegokolwiek sprzeciwu większej wagi. Ten, który pozwala, aby jego własna ciotka chora na schizofrenię zginęła w komorze gazowej, albo by jego pięcioletni syn cierpiący na paraplegię spastyczną otrzymał zastrzyk trucizny, tego nie będzie obchodził los Żydów uznanych za wrogów narodu, ten również pozostanie obojętny w stosunku do dwóch milionów sowieckich więźniów umierających z głodu przez sześć miesięcy po to, by żołnierze niemieccy i ich rodziny mieli więcej jedzenia" ${ }^{18}$. Śmierć stała się dla tych ludzi banałem. Hannah Arendt, która w 1961 roku obserwowała w Jerozolimie proces Eichmanna ${ }^{19}$, była przekonana o tym, że osobista refleksja moralna jest dla człowieka konieczna po to, by nie popadł w „banalność zła" ${ }^{20}$. Według niej Eichmann, jako zbrodniarz wojenny, przestał podejmować jakąkolwiek osobistą refleksję moralną, okazując całkowite posłuszeństwo prawu stanowionemu w nazistowskich Niemczech. Jeśli zatem moralność nie opiera się na miłości i szacunku dla misterium osoby ludzkiej, lecz tylko i wyłącznie na poszanowaniu prawa państwowego, to niebezpieczeństwo depersonalizacji i dehumanizacji osób najsłabszych w społeczeństwie staje się rzeczywistością. Zagrożenie to doskonale odczytał w tym czasie bp Klemens August von Galen, ordynariusz Münster.

\section{OBRONA PODMIOTOWOŚCI OSOBY SEABEJ PRZECIWKO IDEOLOGII EUGENIZMU}

W swoim kazaniu z 3 sierpnia 1941 roku biskup Klemens August von Galen komentuje płacz Jezusa nad Jerozolimą i odnosi go do osobistego lamentu nad społeczeństwem niemieckim. Hierarcha ten posiadał wiedzę popartą dowodami na temat planu eksterminacji chorych i niepełnosprawnych w instytucjach służby

18 G. Aly, dz. cyt., s. 269.

19 Adolf Eichmann (1906-1962), niemiecki funkcjonariusz nazistowski, oficer SS, zbrodniarz wojenny. Po wojnie pojmany i od 1961 roku sądzony w Jerozolimie, skazany na śmierć. Egzekucję wykonano 31 maja 1962 roku przez powieszenie w więzieniu w Ramla. Jego ciało spalono, a prochy rozsypano nad międzynarodowymi wodami Morza Śródziemnego.

20 Zob. H. Arendt, Eichmann w Jerozolimie. Rzecz o banalności zła, Znak, Kraków 1998. 
zdrowia na terenie Westfalii. Ten niemiecki hrabia i od 1933 roku biskup Münster, był znany ze swoich antynazistowskich kazań i stanowczego sprzeciwu wobec ideologii eugenizmu i aktów eutanazji. Jego poparcie wśród wiernych było tak wielkie, że władze hitlerowskie obawiały się go aresztować. Dzięki swej nieugiętej postawie otrzymał przydomek Der Löwe von Münster.

We wspomnianym kazaniu biskup von Galen piętnował ideologię eugenizmu jako podstawę uznania życia osób chorych i niepełnosprawnych za bezwartościowe. Określał ją jako straszną doktrynę, którą państwo przyjęło jako wystarczający powód dla usprawiedliwienia morderstw dokonywanych na niewinnych kobietach, mężczyznach i dzieciach, dla zbrodniczej masakry popełnianej na osobach, które nie są w stanie pracować i produkować ${ }^{21}$. Biskup zauważał, że w tym nieludzkim systemie to instytucja państwowa oceniała przez byle komisję, że pewne osoby, określane jako ,nieproduktywne”, były jak ,stare maszyny, które już nie działają, jakby stary sparaliżowany koń, jakby krowa, która już nie daje mleka"22. Bynajmniej, człowiek nie jest maszyną, ani zwierzęciem, które można oceniać pod kątem produktywności. Wartość osoby nie zależy od jej zdolności produkowania dóbr. Któż może odebrać prawa należne osobie, która nie może już pracować? Biskup von Galen kontynuował: „Jeśli ustanawia się i używa zasady, że można zabić człowieka nieproduktywnego, biada nam wszystkim, którzy będziemy starzy lub osłabieni przez nasz wiek! Jeśli wolno zabijać ludzi nieproduktywnych, biada inwalidom, którzy poświęcili i stracili ich siłę i ich zdrowe kości po to, by odpowiedzieć na ową potrzebę produkcji. Jeśli istnieje prawo usuwania ludzi nieproduktywnych, biada naszym dzielnym żołnierzom, którzy powrócą do domów ciężko zranieni, upośledzeni, jako inwalidzi"23. Przez to proste porównanie biskup wyrażał możliwość słabości i „nieproduktywności” każdego człowieka, który w swej kondycji wulnerabilnej jest nieustannie narażony na utratę autonomii. Nazistowski reżim, rozpoczynając od eksterminacji najsłabszych daje więc wyraz braku jakiegokolwiek respektu dla rzeczywistości człowieczeństwa, które słabość nosi w swojej istocie. Ideologia eugenizmu z jej błędnymi założeniami była jedną z przyczyn takiego podejścia antropologicznego. Tymczasem, misterium człowieczeństwa nie kryje się w jego sile i pożądanej doskonałości kondycji psychofizycznej, lecz w jego realnym bycie, naznaczonym ograniczeniami wynikającymi z jego wulnerabilności. Atak na osobę słabą jest więc w tym wymiarze atakiem na samo człowieczeństwo, na jego misterium ukryte nie tylko w duchowości osoby, lecz przede wszystkim w jego realnym bycie. Do natury tego bytu należą słabość, ograniczenia, zależność. Biskup Klemens August von Galen

21 Zob. T. Knecht, Mgr von Galen, L'évêque qui a défié Hitler, Parole et silence, Paryż 2007, s. 100.

22 C.A. Graf von Galen, Akten, Briefe und Predigten 1933-1946, Ferdinand Schöningh, Paderborn - Monachium 1996, t. 2, s. 877.

23 Tamże, s. 878. 
w prostym języku starał się wykazać błędność założeń antropologicznych nazistowskiej polityki eugenicznej.

W tę politykę wpisana była ideologia zniewolenia jednostki, mającej pozostać obiektem produktywnym i posłusznym reżimowi. Dialektyka świata materializmu miała oddziaływać na osoby, depersonalizując je i redukując do rzeczy. Osoby ludzkie w nazistowskim reżimie totalitarnym pogrążone były w pustce duchowej i anonimowości masy. Produktywizm ten dokonywał się często w pracy niewolniczej. Osoba ciężko niepełnosprawna lub chora psychicznie, jako niezdolna do produkowania, nie była przydatna dla systemu totalitarnego i przez ten fakt stawała się wrogiem jako permanentny konsument ciążący na ekonomii kraju. Jednak w owej ideologii nie chodziło jedynie o argument ekonomiczny. Uboga osoba ludzka jest bowiem świadkiem i obecnością tajemnicy wartości duchowych. W przestrzeni systemu totalitarnego, gdzie więzi międzyludzkie sprowadzone są do relacji posiadania i dominacji, osoba głęboko wulnerabilna nie mogła być jako taka ani posiadana, ani zdominowana. Przez brak możliwości zdominowania jej i zaprzęgnięcia do machiny totalitarnej stała się również wrogiem systemu, ponieważ swoim bytem i obecnością świadczyła o wewnętrznej wolności człowieka i jego godności. Jej byt jest potwierdzeniem istnienia duchowości osoby i sakralności jej natury. Eugenizm XX wieku był więc narzędziem walki z misterium osoby ludzkiej.

\section{Bibliografia}

Aly G., Les Anormaux. Les meurtres par euthanasie en Allemagne (1939-1945), Flammarion, Paryż 2013.

Arendt H., Eichmann w Jerozolimie. Rzecz o banalności zła, Znak, Kraków 1998.

Bracher K.D., Hitler et la dictature allemande. Naissance, structure et conséquence du National-Socialisme, Éd. Complexe, Paryż 1995.

Carrel A., L'homme, cet inconnu, Plon, Paryż 1935.

Galen C.A. von, Akten, Briefe und Predigten 1933-1946, Ferdinand Schöningh, Paderborn-Monachium 1996, t. 2.

Knecht T., Mgr von Galen, L'évêque qui a défié Hitler, Parole et silence, Paryż 2007.

Kulesza W., „Euthanasie - Morde an Polnischen Psychiatriepatient/innen während des Zweiten Weltkriegs”, w: Rotzoll M., Hohendorf G., Fuchs P. i in., Die nationalsozialistische „Euthanasie“-Aktion ,,T4 “ und ihre Opfer. Geschichte und ethische Konsequenzen für die Gegenwart, F. Schöningh, Paderborn/München 2010.

Łangowski M., Wulnerabilność w życiu i filozofii Emmanuela Mouniera, ,Studia Pelplińskie” 2016, t. XLIX. 
Tregenza M., Aktion T4. Le secret d'Etat des nazis: l'extermination des handicapés physiques et mentaux, Calmann-Lévy, Paryż 2011.

\section{Streszczenie}

Francuski lekarz Alexis Carrel w 1935 roku publikuje książkę „Man, The Unknown", w której daje jasny wyraz przyjęcia postawy faworyzującej eugenizm i eutanazję, w szczególności dla ciężkich przestępców nierokujących na resocjalizację. W tym samym czasie w Niemczech Adolf Hitler aplikuje eugenizm jako „terapię oczyszczającą naród z elementu patologicznego". Obydwa wydarzenia wyrastają z przekonania, że postęp ludzkości zależy wyłącznie od najbardziej uzdolnionych, a najbardziej słabi są do wyeliminowania. Ów darwinizm społeczny łączy się ściśle z kryzysem świata, spowodowanym brakiem korelacji pomiędzy postępem duchowym a postępem naukowym i technicznym. Ofiarami tego kryzysu są osoby najsłabsze w społeczeństwie. W świecie, w którym neguje się misterium osoby ludzkiej, człowiek słaby zostaje odrzucony jako bezużyteczny.

Slowa kluczowe: Aktion T4, Carrel Alexis, darwinizm społeczny, eugenizm, eutanazja, misterium osoby, nazizm

Alexis Carrel and Aktion T4 - Eugenics against the Sanctity of Man

\section{Summary}

In 1935 a French physician Alexis Carrel published the book Man, The Unknown in which he clearly showed his support for eugenics and euthanasia (especially in the case of serial criminals with no chance of being reintegrated to the society). At the same time in Germany Adolf Hitler is put into practice an eugenical project presented as a pathology-cleaning therapy for the nation. Both projects are inspired by the belief that the progress of humanity depends only on the most talented and that the weakest ones are to be condemned and eliminated. This social Darwinism is strongly related with the crisis in the world that lacks the correlation between the spiritual and the technical and scientific progress. The victims of this crisis are the weakest members of the society. In a world which denies the sanctity of the person a fragile human being is rejected as useless.

Keywords: Aktion T4, Alexis Carrel, social Darwinism, eugenics, euthanasia, sanctity of the human being, Nazism 